\title{
Measurement of the Sensitivity for Diving-bell Manometer
}

\author{
Jose Eduin Culma Caviedes \\ Instituto Nacional de Metrología, Avenida Carrera 50 \# 26-55 Interior 2, Bogotá D.C., Colombia
}

\begin{abstract}
Diving-bell manometers are devices mainly used for low-gauge measurements, with a variety of industrial and medical applications. At the Colombian Instituto Nacional de Metrología, a Junkalor Dessau TMG 25/1104 diving-bell manometer was subjected to sensitivity verification, with $200 \mathrm{mg}$ as the discrimination threshold. Considering that this manometer works analogously to an equal arm balance, sensitivity is defined as the weight change on the balance that is needed to produce a movement larger that the smallest estimable fraction of a scale interval determined by visual interpolation component (resolution on the indicator element). Three set data points were evaluated: the first, with $20 \mathrm{~g}$ placed on each plate; the second, with $19.7 \mathrm{~g}$ on the left plate and $20 \mathrm{~g}$ placed on the right plate; and the third, with $20.3 \mathrm{~g}$ on the left plate and $20 \mathrm{~g}$ on the right plate. Recommendations for use of the diving bell are made and the resolution for the device was determined.
\end{abstract}

\section{Section: RESEARCH PAPER}

Keywords: diving-bell manometer; sensitivity; low pressure; low-gauge measurement

Citation: Jose Eduin Culma Caviedes, Measurement of the Sensitivity for Diving-bell Manometer, Acta IMEKO, vol. 7, no. 1, article 14, March 2018, identifier: IMEKO-ACTA-07 (2018)-01-14

Section Editor: Jorge Torres-Guzman, CENAM - Centro Nacional de Metrologia, Santiago de Querétaro, Mexico

Received July 14, 2017; In final form November 8, 2017; Published March 2018

Copyright: (C) 2018 IMEKO. This is an open-access article distributed under the terms of the Creative Commons Attribution 3.0 License, which permits unrestricted use, distribution, and reproduction in any medium, provided the original author and source are credited

Funding: This work was supported by Instituto Nacional de Metrología, Colombia. Grant: C-3502-0200-1 Fortalecimiento investigación y desarrollo metrología nacional, SIST-INM

Corresponding author: Jose Eduin Culma Caviedes, e-mail: jeculma@inm.gov.co

\section{INTRODUCTION}

In general terms, according to Lipták [1] and Dryjańska [2], in all inverted bell pressure measuring devices, the bell is immersed into a sealed liquid. The immersion produces a vertical movement that is related to a difference of pressures between the bell's inner and outer surfaces. The bell's movement can be compared to a calibration spring or to its own weight. Depending on the reference side where pressure is measured, this device can detect absolute, positive, negative or differential pressures.

Different kinds of this type of device include single or double bells, with mercury or oil as the immersion liquid, and those designs where the bell's movement is connected to a differential pressure in a linear or square root way (Ledoux) [1]. Moreover, inverted bell pressure measuring devices are used extensively to evaluate very low pressure [2].

The diving bell manometer found at the Instituto Nacional de Metrologia - INM (Colombian National Institute of Metrology) is a VEB Junkalor Dessau TMG 25/1104 model, made in 1982 [3]. This device has a range of measurement between -1000 and $1500 \mathrm{~Pa}$ [4]. This range can be extended to values from - 1 000 to $3000 \mathrm{~Pa}$ when Flourinert FC 40 is used as manometric liquid. Currently, kerosene is used as the operational liquid and this influences the produced pressure values obtained with this device [4].

This diving bell manometer is a single bell device, where the bell is suspended on the right the arm of an equal-arm balance (see Figure 1), weights can be placed on the both arms. According to Constantino et al. [5], small mass variations between one arm and the other are related to positive and negative pressure differentials.

Diving bell manometers, like the one found at INM, have been on the industry for a considerable amount of time. They have a variety of uses, including, but not limited to, air conditioning cost reduction, industrial leakage control and, as a result of recent quality control system implementations, serving as the standard in the calibration of other devices. They are also useful in medical equipment, pressurized rooms, and cleanroom certifications because these places need a controlled atmosphere in order to offer proper working conditions and 


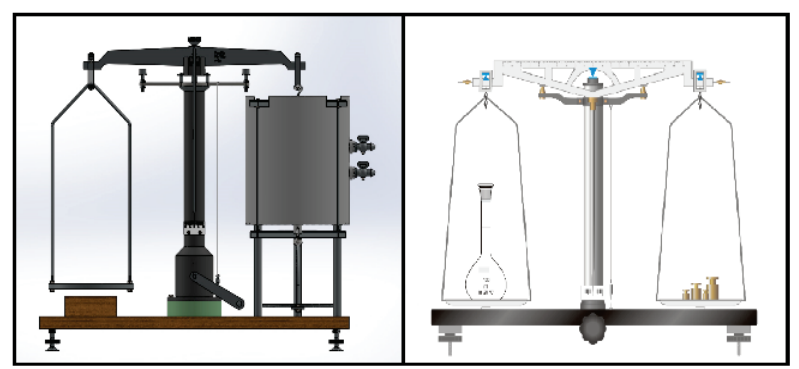

Figure 1. Similarity between a diving bell manometer and an equal-arm balance.

low infection risk [5].

However, inverted bell pressure measuring devices authentic importance is that, even considering that these devices are not traded like in the past, they can be simplified and updated to meet metrology's current needs [5]. Several articles show that they have a consistent use in different laboratories, as seen in works by Rantanen et al. [9], Ahrendt et al. [10], Perkin et al. [11] and Zvizdic et al. [12]. Most of these researchers worked on comparisons between inverted bell pressure measuring devices and other equipment used for analysing low pressure.

Nowadays there are others equipment available in the market that fulfill the Diving-Bell characteristics for lowpressure measurement. Some of the TMG 25/1104 model's characteristics, compared with similar devices can be seen in Table 1.

Inverted bell manometers are highly valued instruments and this is a reason to preserve and maintain them. Sensitivity verification is one of a series of efforts by INM toward this end.

Sensitivity is defined as the smallest weight change on the balance (it is considered that a diving-bell manometer works analogously to an equal arm balance-see Figure 1). This is necessary to produce a movement of a unit of change on the indicator element (in this particular case, the indicator needle) [13]. When the weight is on the left plate, the needle moves to the right. When the weight is on the right plate, the needle moves to the left.

In Section 2, we will discuss the methodology followed to evaluate the sensitivity in the diving-bell manometer, considering its similarity to an equal-arm balance. In the next two sections, results and conclusions will be shown.

Table 1. Comparison of measuring equipment for low pressure.

\begin{tabular}{|c|c|c|c|c|}
\hline & $\begin{array}{c}\text { Diving-bell } \\
\text { manometer } \\
\text { TGM 25/1104 }\end{array}$ & $\begin{array}{l}\text { Piston gauge } \\
\text { manometer } \\
\text { FPG8601 [6] }\end{array}$ & $\begin{array}{l}\text { Low-pressure } \\
\text { micro- } \\
\text { manometer } \\
\text { FC0510 Model } \\
2 \text { [7] }\end{array}$ & $\begin{array}{c}\text { Portable } \\
\text { commercial } \\
\text { manometer } \\
\text { ManoAir 100- } \\
1[8]\end{array}$ \\
\hline Meaurement & -1000 to 3000 & & & \\
\hline pressure range & $\begin{array}{c}\mathrm{Pa}[16] \\
-1000 \text { to } 1500 \\
\mathrm{~Pa}[4]\end{array}$ & 0 to $15000 \mathrm{~Pa}$ & $\begin{array}{c}200 \text { to } 2000 \\
\mathrm{~Pa}\end{array}$ & $\begin{array}{c}-2000 \text { to } 2000 \\
\mathrm{~Pa}\end{array}$ \\
\hline Current status & Discontinued & Discontinued & On the market & On the market \\
\hline Uncertainty & $\begin{array}{c}\text { Not less than } \\
0.3 \mathrm{~Pa}[16]\end{array}$ & $\begin{array}{c} \pm 0.25 \mathrm{~Pa}+ \\
0.003 \text { reading } \\
\text { percentage }\end{array}$ & - & $\begin{array}{c}\text { Between } \pm 0.05 \\
\mathrm{y} \pm 0.2 \mathrm{~Pa}\end{array}$ \\
\hline Special feature & $\begin{array}{l}\text { Positive and } \\
\text { negative } \\
\text { pressures } \\
\text { measurement }\end{array}$ & Reduced noise & $\begin{array}{c}\text { Portability } \\
\text { (weight is just } \\
6 \mathrm{~kg} \text { ) }\end{array}$ & $\begin{array}{l}\text { Positive and } \\
\text { negative } \\
\text { pressures } \\
\text { measurement } \\
\text { and portability }\end{array}$ \\
\hline Manufacturer & VEB Junkalor & $\begin{array}{c}\mathrm{DH} \\
\text { Instruments }\end{array}$ & $\begin{array}{l}\text { Furness } \\
\text { Controls }\end{array}$ & $\begin{array}{c}\text { PCE } \\
\text { Instruments }\end{array}$ \\
\hline
\end{tabular}

\section{METHODOLOGY}

\subsection{Sensitivity analysis}

For each plate, 30 observations were taken: 10 for $20.0 \mathrm{~g}, 10$ for $19.7 \mathrm{~g}$ and 10 for $20.3 \mathrm{~g}$. Certified weights were used, considering established reference parameters [14]. In total, 60 observations were taken. When weights varied in one of the plates, the other maintained a $20.0 \mathrm{~g}$ weight constant, following the instructions on OIML R 76-1 [15].

Three set data points were evaluated:

a) No difference: $20.0 \mathrm{~g}$ in both plates

b) Negative difference: $19.7 \mathrm{~g}$ and $20.0 \mathrm{~g}$

c) Positive difference: $20.3 \mathrm{~g}$ and $20.0 \mathrm{~g}$

These values were taken according to OIML R 76-1 [15]: "sensitivity evaluation must be done adding additional weights with a small impact in order to avoid any effects by discrimination threshold." Keeping in mind that the threshold is $200 \mathrm{mg}$, then $300 \mathrm{mg}$ is a slightly higher value above this threshold.

Observations were taken following the methodology by Zvizdic et al. [12]. Moreover, these observations were randomized to ensure their independence.

According to its calibration certification, the diving-bell manometer is sensitive as long as a weight above $200 \mathrm{mg}$ [16] produces a movement of a segment of scaling. The aim is to prove that a slightly higher weight $(300 \mathrm{mg}$ ) can produce a movement higher than a segment of scaling. The best estimate of an analogue indicating device is determined by visual interpolation we call "AP" the number of times that the needle falls within two adjacent graduation lines [13] [17] [18]. In a practical sense, each segment of scaling was subdivided into 5 AP (see Figure 2). Accordingly, one hypothesis can be considered: the diving-bell manometer is sensitive if there is a significant difference among AP values for no difference versus $\mathrm{AP}$ values for positive and negative differences. In other words, if any AP value is not higher than 5 with additional weights above $200 \mathrm{mg}$, then the diving-bell manometer is not sensitive and it is not under its calibration conditional.

\subsection{Statistical Analysis}

Statistically, data was analyzed with a Kruskal-Wallis test, considering that their distribution was nor normal and that there are repeated values [19]. Keeping this in mind, with the Kruskal-Wallis test, it was possible to establish whether there were or were not significant differences on AP values obtained with no differences in weight and weight differences above the minimum weight defined for this diving-bell manometer sensitivity, according to its calibration certification [16].

\section{RESULTS}

ANOVA statistical methodology might produce unreliable outcome due to the fact that the data is about counting. This fact can affect some ANOVA characteristics such as normality and homoscedasticity. Therefore, the Kruskal-Wallis test is applied to avoid problems with these aforementioned

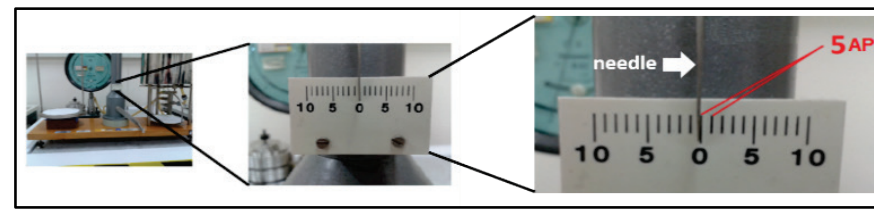

Figure 2. AP is the number of times that the needle falls within the lines. 
characteristics. The null hypothesis is: Ho = The AP averages for different levels of weight variation on the left and right plate should not exceed a minimum AP value of 5 .

For the left plate, obtained data (Table 4), was analyzed with $\mathrm{R}$ Software (Table 6), concluding the information given in (Table 2).

Moreover, this test showed that the highest AP value was for the $19.7 \mathrm{~g}$ level with a 6.5 average, and the lowest AP value was for the $20.3 \mathrm{~g}$ level with a 5.7 average.

Table 2. Kruskal-Wallis test results for the left plate.

\begin{tabular}{l|c}
\hline $\begin{array}{l}\text { Statistic test } \\
\text { p value } \\
\text { Conclusion }\end{array}$ & $\begin{array}{c}\chi^{2}=23.822 \\
p=6.7 \times 10^{-6}\end{array}$ \\
& $\begin{array}{c}\text { With a 95\% confidence level, it is possible to reject the null } \\
\text { hypothesis. This means that there is a highly significant } \\
\text { difference between average AP values for the different } \\
\text { levels of weight variation for the left plate. }\end{array}$ \\
\hline
\end{tabular}

Table 3. Kruskal-Wallis test results for the right plate.

\begin{tabular}{l|c}
\hline Statistic test & \multicolumn{1}{c}{$\begin{array}{c}\chi^{2}=25.215 \\
\text { p value } \\
\text { Conclusion }\end{array}$} \\
$\begin{array}{l}\text { With a 95\% confidence level, it is possible to reject the null } \\
\text { hypothesis. This means that there is a highly significant } \\
\text { difference between average AP values for the different } \\
\text { levels of weight variation for the right plate. }\end{array}$ \\
\hline
\end{tabular}

Table 4. Left plate data and Kruskal-Wallis test.

\begin{tabular}{|c|c|c|c|}
\hline Weight (g) & AP value & Range & $\mathbf{R m}$ \\
\hline 20.0 & 0 & 1 & 5.5 \\
\hline 20.0 & 0 & 2 & 5.5 \\
\hline 20.0 & 0 & 3 & 5.5 \\
\hline 20.0 & 0 & 4 & 5.5 \\
\hline 20.0 & 0 & 5 & 5.5 \\
\hline 20.0 & 0 & 6 & 5.5 \\
\hline 20.0 & 0 & 7 & 5.5 \\
\hline 20.0 & 0 & 8 & 5.5 \\
\hline 20.0 & 0 & 9 & 5.5 \\
\hline 20.0 & 0 & 10 & 5.5 \\
\hline 19.7 & 5 & 11 & 12.5 \\
\hline 20.3 & 5 & 12 & 12.5 \\
\hline 20.3 & 5 & 13 & 12.5 \\
\hline 20.3 & 5 & 14 & 12.5 \\
\hline 19.7 & 6 & 15 & 19.5 \\
\hline 19.7 & 6 & 16 & 19.5 \\
\hline 19.7 & 6 & 17 & 19.5 \\
\hline 20.3 & 6 & 18 & 19.5 \\
\hline 20.3 & 6 & 19 & 19.5 \\
\hline 20.3 & 6 & 20 & 19.5 \\
\hline 20.3 & 6 & 21 & 19.5 \\
\hline 20.3 & 6 & 22 & 19.5 \\
\hline 20.3 & 6 & 23 & 19.5 \\
\hline 20.3 & 6 & 24 & 19.5 \\
\hline 19.7 & 7 & 25 & 27.5 \\
\hline 19.7 & 7 & 26 & 27.5 \\
\hline 19.7 & 7 & 27 & 27.5 \\
\hline 19.7 & 7 & 28 & 27.5 \\
\hline 19.7 & 7 & 29 & 27.5 \\
\hline 19.7 & 7 & 30 & 27.5 \\
\hline
\end{tabular}

For the right plate, obtained data (Table 5), was analyzed with R Software (Table 7), concluding the information provided in (Table 3).

Moreover, this test showed that the highest AP value was

Table 5. Right plate data and Kruskal-Wallis test.

\begin{tabular}{|c|c|c|c|}
\hline Weight (g) & AP value & Range & $\mathbf{R m}$ \\
\hline 20.0 & 0 & 1 & 5.5 \\
\hline 20.0 & 0 & 2 & 5.5 \\
\hline 20.0 & 0 & 3 & 5.5 \\
\hline 20.0 & 0 & 4 & 5.5 \\
\hline 20.0 & 0 & 5 & 5.5 \\
\hline 20.0 & 0 & 6 & 5.5 \\
\hline 20.0 & 0 & 7 & 5.5 \\
\hline 20.0 & 0 & 8 & 5.5 \\
\hline 20.0 & 0 & 9 & 5.5 \\
\hline 20.0 & 0 & 10 & 5.5 \\
\hline 19.7 & 5 & 11 & 16.0 \\
\hline 19.7 & 5 & 12 & 16.0 \\
\hline 19.7 & 5 & 13 & 16.0 \\
\hline 19.7 & 5 & 14 & 16.0 \\
\hline 19.7 & 5 & 15 & 16.0 \\
\hline 19.7 & 5 & 16 & 16.0 \\
\hline 19.7 & 5 & 17 & 16.0 \\
\hline 19.7 & 5 & 18 & 16.0 \\
\hline 19.7 & 5 & 19 & 16.0 \\
\hline 20.3 & 5 & 20 & 16.0 \\
\hline 20.3 & 5 & 21 & 16.0 \\
\hline 19.7 & 6 & 22 & 24.0 \\
\hline 20.3 & 6 & 23 & 24.0 \\
\hline 20.3 & 6 & 24 & 24.0 \\
\hline 20.3 & 6 & 25 & 24.0 \\
\hline 20.3 & 6 & 26 & 24.0 \\
\hline 20.3 & 7 & 27 & 28.5 \\
\hline 20.3 & 7 & 28 & 28.5 \\
\hline 20.3 & 7 & 29 & 28.5 \\
\hline 20.3 & 7 & 30 & 28.5 \\
\hline
\end{tabular}

Table 6. Kruskal-Wallis test data from left plate.

\begin{tabular}{|c|c|c|c|c|c|}
\hline Weight (g) & $\overline{\boldsymbol{r}}$ & $\overline{\boldsymbol{r}}_{\boldsymbol{i}}$ & $\overline{\boldsymbol{r}}_{\boldsymbol{i}}-\overline{\boldsymbol{r}}$ & $\boldsymbol{n}_{\boldsymbol{i}}$ & $n_{i}\left(\bar{r}_{i^{\cdot}}-\overline{\boldsymbol{r}}\right)^{2}$ \\
\hline 19.7 & 15.5 & 23.6 & 8.1 & 10.0 & 656.1 \\
\hline 20.0 & 15.5 & 5.5 & -10.0 & 10.0 & 1000.0 \\
\hline 20.3 & 15.5 & 17.4 & 1.9 & 10.0 & 36.1 \\
\hline \multicolumn{2}{|c|}{ H } & \multicolumn{4}{|c|}{21.834} \\
\hline \multicolumn{2}{|c|}{ Correction } & \multicolumn{4}{|c|}{0.916} \\
\hline \multicolumn{2}{|c|}{$\mathrm{H}^{\prime}$} & \multicolumn{4}{|c|}{23.822} \\
\hline \multicolumn{2}{|c|}{$p$ value } & \multicolumn{4}{|c|}{$6.715 \mathrm{E}-06$} \\
\hline
\end{tabular}

Table 7. Kruskal-Wallis test data from right plate.

\begin{tabular}{cccccc}
\hline Weight (g) & $\overline{\boldsymbol{r}}$ & $\overline{\boldsymbol{r}}_{\boldsymbol{i}}$ & $\overline{\boldsymbol{r}}_{\boldsymbol{i}}-\overline{\boldsymbol{r}}$ & $\boldsymbol{n}_{\boldsymbol{i}}$ & $\boldsymbol{n}_{\boldsymbol{i}}\left(\overline{\boldsymbol{r}}_{\boldsymbol{i}} \cdot-\overline{\boldsymbol{r}}\right)^{2}$ \\
\hline 19.7 & 16.0 & 17.8 & 1.8 & 10.0 & 32.4 \\
20.0 & 16.0 & 6.0 & -10.0 & 10.0 & 1100.0 \\
20.3 & 16 & 25.2 & 9.2 & 10.0 & 846.4 \\
\multicolumn{1}{c}{ H } \\
Correction \\
H' \\
p value
\end{tabular}


for the $20.3 \mathrm{~g}$ level with a 6.2 average, and the lowest AP value was for the $19.7 \mathrm{~g}$ level with a 5.1 average.

\section{CONCLUSION}

Considering that both plates have significant differences and it is possible to conclude that the diving-bell manometer is sensitive due to the fact that the AP values on the plates are always higher than 5.0 AP when weights slightly heavier than $200 \mathrm{mg}$ were placed on the plates. On average, for the left plate, the highest $\mathrm{AP}$ values were $6.5 \mathrm{AP}$ while for the right plate the highest values were $6.2 \mathrm{AP}$.

The sensitivity of $300 \mathrm{mg}$ is equivalent to a pressure of 0.15 $\mathrm{Pa}$, however as the lowest measuring uncertainty for the divingbell manometer is $0.3 \mathrm{~Pa}$, then the contribution of the sensitivity must be included in the uncertainty budget of the diving-bell manometer.

\section{REFERENCES}

[1] B. G. Lipták, "5.9 Manometers", in: Process Measurement and Analysis. B. G. Lipták. CRC PRESS, Boca Raton, 2003, ISBN 08493-1083-0 (v. 1), pp. 766-773.

[2] A. Dryjańska, "Pressure measurement", Metrology laboratory (M-4), (2015), p. 6.

[3] VEB JUNKALOR DESSAU, "Bedienungsanleitung für Feindruck-prüfwaage”, (1982), pp. 1-10.

[4] Laboratorio de Presión-INM, "Instructivo operación de equipos M1-01/L04/I-01”, (2015), pp. 1-72.

[5] P. Constantino, J. Camacho, A. Maciel, A. Acquarone "Diseño de un instrumento de bajo costo para la calibración de micromanómetros diferenciales", INNOTEC 2014, 9 (14 - 18), vol. 9, (2014), pp. 1-5.

[6] D. H. Instruments and Fluke Company, "FPG8601TM/VLPCTM Operation and Maintenance Manual”, (2007), pp. 1-166.
[7] Furness Controls, "Microprocessor Micromanometer FC0510", (2017), pp.1-2.

[8] P. C. E. Instruments, "Manómetro de presión ManoAir100-1," (2017), pp.1-2.

[9] M. Rantanen, S. Semenoja, G. Peterson, J. Busk, "Low gauge pressure comparisons between MIKES, Metrosert and FORCE Technology Range -2000 Pa to +2000”, MIKES Publication, 2007, pp. 1-22.

[10] H. Ahrendt, J. Könemann, W. Sabuga, et al., "Final Report on COOMET Key Comparison of National Pressure Standards in the Range $100 \mathrm{~Pa}$ to $5 \mathrm{kPa}$ of Gauge Pressure (COOMET. M.PK14)", versión 1, 2011, pp. 1-27.

[11] M. Perkin, C. Rendle, J. Jäger, et al., "Comparison of low differential pressure standards in the range $3 \mathrm{~Pa}$ to $1000 \mathrm{~Pa}$," Metrologia, 36, 1999, pp. 1-34.

[12] D. Zvizdic, L. G. Bermanec, W. Schultz, T. Veliki, "Characterization of LPM diving-bell manometer," IMEKO 20th TC3, 3rd TC16 1st TC22 Int. Conf., p. 6, 2007.

[13] S. V. Gupta, "Chapter 2 Two-Pan Equal-Arm Balances", in: Mass Metrology. Springer Series in Materials Science. Springer-Verlag, Berlin Heidelberg, 2012, ISBN 978-3-642-23412-5, pp. 19-30.

[14] SCI, "Proceso de calibración M-004 para balanza de dos platos con brazos iguales", Madrid, 1991, pp. 1-22.

[15] International Organization of Legal Metrology, "OIML R 761:2006, Non-automatic weighing instruments. Part 1: Metrological and technical requirements", OIML, Paris-Francia, 2006, pp. 25-27.

[16] Physikalisch-Technische Bundesanstalt, "Calibration Certificate PTB 30050",(2014), pp. 1-4.

[17] DKD-R 6-1, "Calibration of Pressure of Gauge”,(2014), p. 28.

[18] R. Idrovo, "Informe de prueba y puesta en funcionamiento del manómetro de campana de inmersión NIM 45008.," Bogotá D.C.-Colombia, 2011, pp. 1-40.

[19] W. Kruskal, W. Wallis, "Use of ranks in one-criterion variance analysis", Journal of the American Statistical Association, Vol 47, (1952), pp. 583-621. 